\title{
THERMOSTABILITY OF ANTIOXIDANT AND DETERIORATIVE ENZYMES FROM SOURSOP AND CASHEW APPLE JUICES ${ }^{1}$
}

\author{
MARCELA CRISTINA RABELO², EDY SOUSA DE BRITO, \\ CARLOS FARLEY HERBSTER MOURA ${ }^{4}$, LUCIANA DE SIQUEIRA OLIVEIRA ${ }^{5}$, \\ MARIA RAQUEL ALCÂNTARA DE MIRANDA ${ }^{6}$
}

ABSTRACT - This study aimed to evaluate the thermostability of antioxidant (superoxide dismutase SOD, catalase - CAT and ascorbate peroxidase - APX) and deteriorative (guaiacol peroxidase - G-POD, polyphenoloxidase - PPO, pectin-methylesterase - PME and polygalacturonase - PG) enzymes from soursop and cashew apple juices. Juices were prepared homogenizing ripe fruit pulps and submitting to different thermal treatments $\left(55,65,75,85\right.$ and $\left.95^{\circ} \mathrm{C}\right)$ for different time period $(1,3,5,10,15,20$ and $30 \mathrm{~min})$ then enzymatic activities were evaluated. The treatments at $55^{\circ} \mathrm{C}$ for soursop juice and at $75^{\circ} \mathrm{C}$ for cashew apple juice presented the best results, considering the low residual activities for deteriorative enzymes and the retained activity of SOD. Our results suggest appropriate technological condition to thermal processing from soursop and cashew apple juice whereby ensuring quality beyond their functionality.

Index terms: pasteurization, enzyme kinetics, thermal inactivation, Annona muricata, Anacardium occidentale.

\section{ESTABILIDADE TÉRMICA DE ENZIMAS ANTIOXIDANTES E DETERIORANTES DOS SUCOS DE GRAVIOLA E CAJU}

RESUMO- Este trabalho objetivou avaliar a estabilidade térmica de enzimas antioxidantes (superóxido dismutase - SOD, catalase - CAT e ascorbato peroxidase - APX) e deteriorantes (guaiacol peroxidase - G-POD, polifenol oxidase - PPO, pectinametilesterase - PME e poligalacturonase - PG) em sucos de graviola e de caju. Os sucos foram preparados homogeneizando a polpa das frutas maduras e submetendoos a diferentes tratamentos térmicos $\left(55,65,75,85\right.$ e $\left.95^{\circ} \mathrm{C}\right)$ em diferentes períodos de tempo $(1,3,5,10$, 15,20 e 30 minutos) e, posteriormente, as atividades enzimáticas foram avaliadas. Os tratamentos a $55^{\circ} \mathrm{C}$ para o suco de graviola e a $75^{\circ} \mathrm{C}$ para o suco de caju apresentaram os melhores resultados, considerando as baixas atividades residuais para as enzimas deteriorantes e manutenção da SOD. Nossos resultados sugerem condições tecnológicas adequadas para o processamento térmico do suco de graviola e de caju, pelo qual é assegurada a sua qualidade, além de sua funcionalidade.

Termos para Indexação: pasteurização, cinética enzimática, inativação térmica, Annona muricata, Anacardium occidentale.

\footnotetext{
${ }^{1}$ (Trabaho 108-15). Recebido em: 16-04-2015. Aceito para publicação em: 22-07-2015.

${ }^{2}$ Bióloga, Mestre em Bioquímica, Universidade Federal do Ceará - marcelacrabelo@gmail.com ${ }^{3}$ Químico Industrial, Pesquisador III, Embrapa Agroindústria Tropical - edy.brito@embrapa.br ${ }^{4}$ Eng. Agronomo, Pesquisador A, Embrapa Agroindústria Tropical - farley.moura@embrapa.br

${ }^{5}$ Eng. Alimentos, Doutora em Bioquímica, Universidade Federal do Ceará - luciana.soy@gmail.com

${ }^{6}$ Professor Adj. I, Universidade Federal do Ceará/DBBM - raquelamiranda@gmail.com
} 


\section{INTRODUCTION}

The consumers demand for fresh and high-quality fruit juices finds an obstacle on the susceptibility of such products to spoilage, thereby, limiting its limited shelf-life. To extend the conservation period maintaining quality, commercial fruit juices are generally pasteurized and have preservatives added (JORDAN et al., 2001). Thermal treatments are used to maintain the food product stability through inactivation of microorganisms and denaturation of several enzymes, however, have been associated with a negative effect on juice sensorial and nutritional properties (CORREIA et al., 2008), especially with the deterioration of aromatic and flavor-associated compounds that are volatile, some thermolabile vitamins, moreover may damage several constituents with human health-protecting and shelflife-extending potential as natural antioxidants, including radical-scavengers enzymes, as superoxide dismutase (SOD, EC 1.15.1.1) and catalase (CAT, EC 1.11.1.6), that eliminate reactive oxygen species (ROS) which increases under stressful conditions (processing).

Investigation of natural antioxidants for food preservation has received much attention supplied by a general resistance from both consumers and food industry to synthetic additives due to the possibility of health-hazardous effects of these unnatural preservatives (MEYER; ISAKSEN, 1995). Therefore, antioxidant enzymes, besides the well-known non-enzymatic antioxidants, represent an alternative for exploiting natural constituents as radical-scavenging agents in plant foods. Carillon et al. (2014) investigated the effects of supplementation of SOD-concentrated extract from melon on psychological stress, physical and mental fatigue in healthy humans and reported a reduction in both stress and fatigue variables through the enhancement of endogenous antioxidant defense and subsequent, reduction of oxidative stress. Lallès et al. (2011) also reported that melon pulp SOD-rich fraction, a dosage equivalent to $50 \mathrm{UEA} / \mathrm{kg}$ for 12 days, was effective in lowering the stress proteins levels along the gastrointestinal tract of pigs after weaning.

Other naturally occurring enzymes found in fruits, however, may lead to product deterioration, as peroxidase (POD, EC 1.11.1) and polyphenoloxidase (PPO, EC 1.14.18.1), which are responsible for the development of off-flavors and darkening reactions, through the development of browning pigments (MIKA; LUTHJE, 2003, PASSARDI et al., 2005). Cell wall hydrolytic enzymes pectin-methylesterase (PME, EC 3.1.1.11) and polygalacturonase (PG;
EC 1.2.1.15) act together lowering viscosity and thereby, quality and consumer acceptance for fruit juices. The same plant cell wall degrading enzymes are also employed by the industry to reduce viscosity and improve the clarification process of some juices (GUMMADI; PANDA, 2003). Based on the diverse possibilities of requirements for enzymes from the various fruit species used by the juice industry, the kinetic parameters of enzyme inactivation are of great importance for the process design and industrialization of such produce.

The soursop (Annona muricata L), considered the most tropical among the Annonaceae family, presents great agronomical potential to be commercialized as juice as the fruit has substantial, sweet flavored, soft, white pulp and, moreover, is a good source of complex B vitamins (ABBO et al., 2006, LIMA et al., 2006). The cashew tree (Anacardium occidentale L.) is native of Brazil and its main commercial product is the nut, thereby the peduncle or cashew apple was considered a residue of the nut industry. The fragility of the cashew apple strongly limits its postharvest handling and storage, therefore processing into juice has become an excellent alternative. However, in 2012, Brazil that is the largest grower worldwide produced over 1.8 million tons of peduncles, but only $15 \%$ was destined for juice production (FAO 2014).

Despite their importance and agronomical potential, these two fruit species have not been thoroughly evaluated regarding their enzyme activity or kinetic parameters. Thereby, the objectives of this study were to evaluate the effect of the thermal treatment on the residual activity and kinetic behavior of antioxidant, cell wall hydrolytic and browning enzymes in both soursop and cashew apple juices.

\section{MATERIAL AND METHODS}

\section{Fruit Processing and Thermal Inactivation} Experiments

Ripe soursop (Annona muricata L. cv. Crioula) fruits, with soft spikes, were peeled and seeds were removed to yield $4 \mathrm{Kg}$ of pulp which were processed in domestic blender with distilled water, 1:1. Red ripe cashew apples $(4 \mathrm{Kg}$, Anacardium occidentale L. clone CCP 76) were washed in distilled water, nuts were removed and the juice was obtained using a juicer "expeller" extractor $\left(\right.$ CEIL $\left.^{\circledR}\right)$, without water addition. All procedures were carried out at room conditions.

Since thermal processing (pasteurization) of fruit juices is usually not higher than $100^{\circ} \mathrm{C}$, (PAEPE et al. 2014), the experiment was carried 
out as follows: $50 \mathrm{~mL}$ of soursop and cashew apple juices prepared as described before were incubated in glass tubes in hot water bath (Nova Ética ${ }^{\circledR}$ ) at 55 , $65,75,85$ and $95^{\circ} \mathrm{C}$ for periods of $1,3,5,10,15,20$ and $30 \mathrm{~min}$. Upon completion of thermal processing, samples were immediately cooled in ice-bath. Samples were packed in polyethylene bags and stored in ultra-freezer at $-80^{\circ} \mathrm{C}$ (Sanyo ${ }^{\circledR}$ MDF-U3086S) for subsequent determination of the residual enzymatic activity. For each temperature test, the activity of control samples $\left(\mathrm{A}_{0}\right)$, kept at room temperature, was evaluated and all experiments were done in triplicate.

\section{Enzyme Assays}

Juice samples $(1 \mathrm{~g})$ were homogenized (Turrax ${ }^{\circledR}$ T25 Digital) with $5 \mathrm{~mL}$ ice-cold extraction buffer [100 mM potassium-phosphate buffer ( $\mathrm{pH} 7.0)$ and $0.1 \mathrm{mM}$ EDTA]. The homogenate was filtered through a muslin cloth and centrifuged at $3,200 \mathrm{~g}$ for $40 \mathrm{~min}$. The supernatant fraction was used as crude extract for the antioxidant enzyme activity assays and all the procedures above were performed at $4^{\circ} \mathrm{C}$. The total protein content was determined according to Bradford (1976).

Superoxide dismutase (SOD, EC 1.15.1.1) activity was determined spectrophotometrically on the basis of the inhibition of the photochemical reduction of NBT (Sigma) (GIANNOPOLITIS; RIES, 1977). The reaction mixture (1.5 mL) absorbance was measured by a Spectrum SP 2000UV spectrophotometer at $560 \mathrm{~nm}$, and 1 unit of SOD activity (UA) was defined as the amount of enzyme required causing a $50 \%$ reduction in the NBT photoreduction rate (BEAUCHAMP; FRIDOVICH, 1987). Thus, results were expressed as unit of activity (UA). $\mathrm{mg}^{-1}$ protein $(\mathrm{P})$.

Guaiacol peroxidase (G-POD, EC 1.11.1.7) activity was assayed according to Amanko et al. (1994). Initially, $100 \mathrm{mM}$ phosphate buffer ( $\mathrm{pH} 7.0$ ), $0.1 \mathrm{mM}$ EDTA were incubated at $30^{\circ} \mathrm{C}$ for $10 \mathrm{~min}$ and then, $0.2 \mathrm{M}$ guaiacol (Merck $\left.{ }^{\circledR}\right), 0.03 \mathrm{mM} \mathrm{H}_{2} \mathrm{O}_{2}$ and $50 \mu \mathrm{l}$ enzyme extract were added to complete the reaction mixture $(2 \mathrm{~mL})$. Enzyme activity was measured through absorbance at $470 \mathrm{~nm}$ and the results expressed in $\mu \mathrm{mol} \mathrm{H}_{2} \mathrm{O}_{2} \cdot \mathrm{mg}^{-1} \mathrm{P}$. $\mathrm{min}^{-1}$.

Ascorbate peroxidase (APX, EC 1.11.1.1) activity was assayed according to the method of Nakano and Asada (1981). Enzyme activity was measured at $290 \mathrm{~nm}$ and using the molar extinction coefficient for ascorbate $\left(2.8 \mathrm{mM} . \mathrm{cm}^{-1}\right)$, considering that $1 \mathrm{~mol}$ of ascorbate is required for a reduction of $1 \mathrm{~mol}$ of $\mathrm{H}_{2} \mathrm{O}_{2}$. Results were expressed in $\mu \mathrm{mol}$ $\mathrm{H}_{2} \mathrm{O}_{2} \cdot \mathrm{mg}^{-1}$ P. $\mathrm{min}^{-1}$.

Catalase (CAT, EC 1.11.1.6) activity was measured according to the method of Beers and Sizer (1952). The reaction started by adding the enzyme extract, and then the decrease in hydrogen peroxide $\left(\mathrm{H}_{2} \mathrm{O}_{2}\right.$, Merck $\left.{ }^{\circledR}\right)$ was monitored through absorbance at $240 \mathrm{~nm}$ and quantified by its molar extinction coefficient $\left(36 \mathrm{M}^{-1} \mathrm{~cm}^{-1}\right)$. One unit of CAT activity (UA) was defined as the amount of enzyme required to decompose $\mathrm{H}_{2} \mathrm{O}_{2}\left(\mu \mathrm{mol} \mathrm{H}_{2} \mathrm{O}_{2} \mathrm{~min}^{-1}\right)$ and the results were expressed as $\mu \mathrm{mol} \mathrm{H} \mathrm{H}_{2} \mathrm{O}_{2}$. $\mathrm{mg}^{-1} \mathrm{P}$. $\mathrm{min}^{-1}$.

Polyphenoloxidase activity (PPO, EC 1.14.18.1) was measured spectrophotometrically by the method described by Wisseman and Lee (1980) using catechol as substrate. Juice (5 g) was homogenized (Turrax ${ }^{\circledR}$ T25 Digital) with 10 $\mathrm{mL}$ of $50 \mathrm{mM}$ potassium phosphate buffer, $\mathrm{pH}$ 7 containing $1 \%$ soluble polyvinyl pyrrolidone (PVP) and centrifuged at 3,000 $\mathrm{g}$ for $40 \mathrm{~min}$. The supernatant fraction was used as a crude extract for enzyme activity assays and all the procedures above were performed at $4{ }^{\circ} \mathrm{C}$. The total protein content was determined according to Bradford (1976)

The reaction mixture $(2.15 \mathrm{~mL})$ constituted of $0.1 \mathrm{M}$ phosphate buffer ( $\mathrm{pH}$ 6.0) contained $0.1 \mathrm{M}$ catechol and $300 \mu \mathrm{l}$ enzyme extract were incubated at $30^{\circ} \mathrm{C}$ for $30 \mathrm{~min}$. The reaction was stopped adding $800 \mu \mathrm{l}$ of $0.2 \mathrm{~N}$ perchloric acid and reaction mixture was centrifuged at 3,248 $\mathrm{x} g$ for $5 \mathrm{~min}$. The supernatant fraction was subjected to reading in the spectrophotometer at $395 \mathrm{~nm}$. The activity was expressed as $\Delta$ Abs. $\mathrm{min}^{-1}$.mg P.

Pectinmethylesterase (PME, E.C. 3.1.1.11) was extracted and measured using modifications of the method of Korner et al. (1980). Juice (5 g) was homogenized with $20 \mathrm{~mL}$ of ice-cold $0.2 \mathrm{~N} \mathrm{NaCl}$, in a Polytron. The homogenate was filtered through Whatman No. 1 paper and the residue collected as the enzyme crude extract. For PME activity assay (Kertesz 1955), the reaction mixture contained $5 \mathrm{~mL}$ of enzyme crude extract and $30 \mathrm{ml}$ of pectin solution $(1 \% \mathrm{v} / \mathrm{w}$ citrus pectin in $0.2 \mathrm{M} \mathrm{NaCl}, \mathrm{pH} 7)$ and the rate of pectin demethylation was monitored through titration with $\mathrm{NaOH} 0.1 \mathrm{M}$ at $\mathrm{pH} 7.0$ for $10 \mathrm{~min}$. One unit of pectinmethylesterase was defined as the amount of enzyme capable of demethylating pectin corresponding to the consumption of $1 \mathrm{nmol} \mathrm{NaOH}$. $\mathrm{min}^{-1} \cdot \mathrm{g}^{-1}$ and results were expressed as UA.mg ${ }^{-1}$ of $\mathrm{P}$.

Polygalacturonase (PG, E.C. 3.2.1.15) was extracted as described by Buescher and Furmanski (1978) and its activity determined according to Pressey (1986). Juice (12.5 g) was homogenized (Turrax ${ }^{\circledR}$ T25 Digital) with $25 \mathrm{~mL}$ of ice-cold water. The homogenate was centrifuged at 3,248 $\mathrm{x} g$ for 10 $\min$ at $4^{\circ} \mathrm{C}$ and then, the precipitate was resuspended in $10 \mathrm{~mL}$ of distilled water and centrifuged as before. 
The precipitate was suspended in $20 \mathrm{~mL}$ of $1.0 \mathrm{~N}$ $\mathrm{NaCl}$, stirred for $1 \mathrm{~min}$ and then, adjusted to $\mathrm{pH} 6.0$ and let to rest for $1 \mathrm{~h}$. The volume was completed to $30 \mathrm{~mL}$ with $1.0 \mathrm{~N} \mathrm{NaCl}$, centrifuged at 3,248 $\mathrm{g}$ for $10 \mathrm{~min}$ at $4^{\circ} \mathrm{C}$ and the supernatant was collected as the enzyme crude extract. All previous steps were conducted at $4^{\circ} \mathrm{C}$. For $\mathrm{PG}$ activity assay, the reaction mixture consisted of $200 \mu \mathrm{L}$ enzyme crude extract plus $50 \mu \mathrm{L} 0.25 \%$ polygalacturonic acid in $37.5 \mathrm{mM}$ sodium acetate buffer, $\mathrm{pH}$ 5.0. The reaction mixture was incubated for $3 \mathrm{~h}$ at $30^{\circ} \mathrm{C}$ followed by a boiling water bath to stop the reaction. The reducing groups liberated were determined according to Somogyi technique modified by Nelson (1944). Results were expressed as UA.mg-1 of P.

\section{Data Analysis}

In isothermally-processed foodstuff, enzymatic inactivation are modeled using firstorder kinetic model frequently expressed by $k$ and $D$ values, as $k$ represents the inactivation rate constant $\left(\mathrm{min}^{-1}\right)$ and $D$ is the time period (min) necessary for the enzyme to lose $90 \%$ of its activity (TEREFE et al 2009). Therefore, as enzymes inactivate due to rising temperatures, this is observed by an increase in $k$ and a decline of $D$ values. The rate constant $k$ for firstorder inactivation was determined from the slopes of the inactivation time courses according to Eq. 1

$$
\log \left(A / A_{0}\right)=-(k / 2.303) t
$$

where $A_{0}$ is the mean initial enzyme activity and $A$ is the mean activity after heating for time $t$. The slopes of these lines were determined by linear regression and the calculated rate constants were replotted in Arrhenius plots, expressed as residual activity $\left(\% A / A_{o}\right)$.

A $D$ value, the time required to reduce the enzyme activity to $10 \%$ of its original value, is directly related to an inactivation rate constant $k$ by Eq. 2:

$$
\mathrm{k}=2.303 / \mathrm{D}
$$

\section{RESULTS AND DISCUSSION}

Although, SOD is a key enzyme in protective mechanisms against oxidative stress (SANTOS et al., 2000, MORAN et al., 2003), there is no previously published literature on its thermal stability or kinetic behavior. Initially, SOD activity from soursop juice was 10.7 UA.mg ${ }^{-1} \mathrm{P}$ and its thermal inactivation was accomplished after $30 \mathrm{~min}$ at $65^{\circ} \mathrm{C}$, when the residual activity was reduced to $6.7 \%$ (Fig. 1A). At higher temperatures, SOD was thoroughly inactivated after $5 \mathrm{~min}$ as shown by the non-linear residual activity plot, however heating at $55^{\circ} \mathrm{C}$ for 5 min did induce a peak of $150 \%$ residual activity. At this lower temperature, the inactivation kinetics showed a $D$ value of $767.7 \mathrm{~min}$ which corresponds to an inactivation rate constant $k$ of $0.003 \mathrm{~min}^{-1}$ (Table 1) evidencing its great stability. On the other hand, SOD's increasing sensitivity to higher temperatures was also proven by the greater $k$ values, $0.262 \mathrm{~min}^{-1}$ at $95^{\circ} \mathrm{C}$, and much smaller $D$ values, $8.8 \mathrm{~min}$.

SOD from cashew apple juice was initially 7.14 UA.mg ${ }^{-1} \mathrm{P}$ and resistant to inactivation (Fig. 1B) as exposure do $95^{\circ} \mathrm{C}$ resulted in a decline in activity after $1 \mathrm{~min}$ and then, a recovery to $74 \%$ after $30 \mathrm{~min}$. At this higher temperature, $D$ value demonstrated that it would take $383 \mathrm{~min}$ to reduce in $90 \%$ cashew juice SOD activity (Table 1 ). The $k$ values were very low corroborating to the idea that cashew SOD was very stable.

Catalase converts $\mathrm{H}_{2} \mathrm{O}_{2}$ into $\mathrm{H}_{2} \mathrm{O}$ and $\mathrm{O}_{2}$ and is considered one of the most active antioxidant enzymes in vegetables (BREUSEGEM et al., 2001). However, no catalasic activity was found for soursop juice, but only for cashew apple juice which was initially $74 \mu \mathrm{mol} \mathrm{H}_{2} \mathrm{O}_{2} \cdot \mathrm{mg}^{-1}$ P.min ${ }^{-1}$ (Fig. 2). In cashew apple juice, CAT activity varied, therefore it is easier to explain the behavior through the enzyme kinetics (Table 1). Low $k$ values indicate thermal stability and as may be observed for the $D$ values which were 329 $\min$ at $55^{\circ} \mathrm{C}$ and declined to $95.9 \mathrm{~min}$ at $95^{\circ} \mathrm{C}$. The result suggests there are CAT isoforms with different heat resistances which would explain the inconstancy in the residual activity, although, there is no other published data on CAT thermal stability.

Differently from CAT and SOD, peroxidase has been the object of several studies regarding its activity and kinetics (MATSUI et al., 2008, JAKOB et al., 2010, RAYAN et al., 2011). Soursop and cashew apple juices were evaluated for both peroxidases, however APX activity was found only in cashew apple juice and G-POD, only in soursop juice (initially $0.018 \mu \mathrm{mol} \mathrm{H}_{2} \mathrm{O}_{2} \cdot \mathrm{mg}^{-1} \mathrm{P} \cdot \mathrm{min}^{-1}$ ). Heating at $55{ }^{\circ} \mathrm{C}$ promoted a slow decline in soursop juice G-POD with residual activity of $54 \%$ after $30 \mathrm{~min}$ (Fig. 3A). Inactivation of G-POD was observed after only $1 \mathrm{~min}$ at $65{ }^{\circ} \mathrm{C}$ or higher temperatures, showing its great thermolability and a first-order kinetic, however at times longer than $1 \mathrm{~min}$, there is an obvious deviation from linearity. Freitas et al. (2008) thermally treated 'Benitaka' and 'Ruby' grape juices and observed that G-POD inactivation behavior was not linear, as the greatest activity loss occurred after $10 \mathrm{~min}$ at $85^{\circ} \mathrm{C}$ and afterwards, it was not completely inactivated. 
In cashew apple, the residual APX activity declined from $0.6 \mu \mathrm{mol} \mathrm{H}_{2} \mathrm{O}_{2} \cdot \mathrm{mg}^{-1} \mathrm{P} \cdot \mathrm{min}^{-1}$ at the first minute and then increased, especially at $55^{\circ} \mathrm{C}$ reaching $80 \%$ of its activity at the end of the $30 \mathrm{~min}$ (Fig. 3B). For all tested temperatures, the greatest reduction in activity was observed after 20 min of heating. The results show the lowest temperature treatment $\left(55^{\circ} \mathrm{C}\right)$ enhanced APX activity, meanwhile at higher temperatures resulted in a decrease up to 20 min of exposure and a slight increase after $30 \mathrm{~min}$. This final increase may be explained by the activation of thermoresistant isoforms under such conditions.

In contrast with APX, G-POD activity was not detected in cashew apple juice indicating that possible changes in color quality are not due to phenolic peroxidation by this enzyme. Corroborating with this idea, Damasceno et al. (2008) reported that browning observed during storage of cashew juice and after thermal treatment was due to vitamin $\mathrm{C}$ degradation and not to enzyme activity. Peroxidase belongs to a group of oxide-reductases able of catalyzing a great number of oxidative reactions that result in color and flavor changes in fruits and its derivatives. Ascorbate peroxidase catalyzes $\mathrm{H}_{2} \mathrm{O}_{2}$ reduction using the reducing power of ascorbate (APX) (NOCTOR; FOYER, 1998), meanwhile G-POD is an isoform that uses phenolics such as guaiacol (o-metoxiphenol) as reducing agent. The oxidation of phenolics results in dark colored compounds that interfere with product quality (TAYEFI-NASRABADI et al., 2011). To prevent these undesirable reactions, thermal treatments are usually used to inactivate these enzymes and preserve product quality.

The kinetic for soursop juice G-POD showed increasing $k$ and declining $D$ values at temperatures above $65^{\circ} \mathrm{C}$ (Table 1), when $D$ value was $12.1 \mathrm{~min}$ and $k$ was $0.19 \mathrm{~min}^{-1}$. The increase in inactivation rate constant reflects the low thermostability of soursop juice G-POD at higher temperatures. In cashew apple, there was a decline in residual APX activity and according to the null $k$ value observed; APX was not inactivated at $55^{\circ} \mathrm{C}$ contrasting with the results for the remaining temperatures. A fast inactivation was also observed for CXD 199 tomato juice at $70^{\circ} \mathrm{C}$ as $k$ value was $0.03 \mathrm{~s}^{1}$ and $D$ was $1.5 \mathrm{~min}$ (ANTHON et al., 2002). When broccolis juice were evaluated regarding the two present POD isoforms, two different $k$ values were found, 0.02 and $0.26 \mathrm{~min}^{-1}$ (POŁATA et al., 2009). Information on this kinetic parameter for POD, which reflects the difference in isoform stability, is useful when determining the most efficient inactivating condition.

POD has been considered a thermoresistant enzyme by Jakob et al. (2010) who reported that POD from carrot juice remained active after 150 min at $70^{\circ} \mathrm{C}$. Although, a study with soursop pulp reported a decline of 57\% in POD activity after only 1 second at $70^{\circ} \mathrm{C}$ (TEIXEIRA et al., 2006). These latter authors considered POD completely inactivated after pasteurization at $80^{\circ} \mathrm{C}$ and affirmed the treatment was efficient in keeping product quality during storage. Another study with POD from orange juice showed its complete inactivation at temperatures above $62^{\circ} \mathrm{C}$ (HIRSCH et al. 2008) and Anthon et al. (2002) also reported that POD from tomato CXD 199 juice was quickly inactivated at $72^{\circ} \mathrm{C}$.

The different inactivation patterns reported may be explained by the variety of POD forms present in superior plants, as more than 40 genes encode several isoforms which can also be generated by posttranscriptional and translational modifications (DE MARCO et al., 1995). Moreover, Hirsch et al. (2011) concluded that POD activity varied greatly among cultivars of different Citrus species and therefore, could not be used as freshness indicator. Previously, POD was inactivated at temperatures above $76^{\circ} \mathrm{C}$ for periods longer than $30 \mathrm{~s}$ (CLEMENTE, 2002). Abbo et al. (2006) observed an acidification of soursop juice after pasteurization and this may also contribute to its low thermoresistance, reported here. Matsui et al. (2008) reported that POD thermal resistance may also be influenced by medium composition, besides $\mathrm{pH}$, as enzymes naturally occurring in coconut water were more resistant than commercial ones added to sterile coconut water.

Polyphenoloxidase activity was not observed in either juices studied, which can be explained by protein denaturation as a consequence of the preparation of juices or the assay method employed.

Initially, PME activity from soursop juice was 7128.1 UA.mg ${ }^{-1} \mathrm{P}$ and was very resistant to thermal inactivation (Fig. 4A). At all temperatures, PME activity was reduced in the first minute and then, stabilized. Initially, at $55^{\circ} \mathrm{C}$, the residual activity declined $15 \%$ while at 85 and $95^{\circ} \mathrm{C}$, the activity declined $30 \%$. The $95^{\circ} \mathrm{C}$ treatment caused the greatest reduction in PME activity reaching 39\%, after $30 \mathrm{~min}$. These results show that PME thermal inactivation results were much lower than necessary to maintain quality attributes as viscosity, therefore, higher temperatures or longer periods would be more efficient. Viscosity is one of the most important physical quality attributes of fruit juices and, thus has been a target of conservation treatments as thermal inactivation of cell wall hydrolytic enzymes as PME and PG (RIVAS et al., 2006).

PME activity from cashew apple juice was 
initially 501.8 UA.mg $^{-1} \mathrm{P}$ and was enhanced up to 10 times at $55^{\circ} \mathrm{C}$ (Fig. 4B). At 65 and $85^{\circ} \mathrm{C}$, there was an initial increase followed by a decline to the end of 15 and 20 min, respectively, when activity again increased. The remaining treatments did not significantly affect PME activity when compared to control. The results suggest that PME from cashew apple is thermostable and has a high optimum temperature, meanwhile in guavas, the optimum temperature for this enzyme ranges from 75 to $85^{\circ} \mathrm{C}$ (LEITE et al., 2006).

The kinetic parameters for PME activity from soursop showed how the enzyme was little affected by the thermal treatment, thereby, $109,6 \mathrm{~min}$ at $95^{\circ} \mathrm{C}$ $(D)$ should be necessary to reduce its activity in $90 \%$ (Table 1). Due to the enzyme stability, $k$ values increased from 0.012 to only $0.021 \mathrm{~min}^{-1}$ from 55 to $95^{\circ} \mathrm{C}$. As stated above and may be confirmed by the kinetic parameter, PME from cashew juice was thermoresistant and according to the inactivation constant, PME would never be inactivated at 55 and $65^{\circ} \mathrm{C}$ and beyond those temperatures, inactivation would happen slowly. Anthon et al. (2002) reported $D$ values of 7.2 and 10.4 min for thermal inactivation of PME in BOS 3155 and CXD-199 tomato juices at $70{ }^{\circ} \mathrm{C}$, respectively. The discrepancies found among PME kinetic values may be explained by the fact that some studies were developed on fruit juices or purees, whereas others had carried used enzymatic extracts. In general, an enzyme is more stable in whole or homogenous plant tissue, where it is protected by components as proteins, carbohydrates and pectin when compared to its pure form (MATSUI et al. 2008).

PME catalyzes the de-esterification of pectin liberating less esterified pectic acid; meanwhile Polygalacturonase (PG) hydrolyses pectic acid leading to loss of viscosity and separation of phases during the juice storage. Different PME isoforms may present different heat stabilities as proposed by MacDonald et al. (1997), who isolated four PME isoforms from lemon and observed that one of them had great thermal stability maintaining its activity after $9 \mathrm{~min}$, at $86^{\circ} \mathrm{C}$. The same authors attributed the deterioration of lemon juice to the thermostability of such isoform. Other contrasting results were observed with PME from acerola (Malpighia emarginata) which reduced its activity in $90 \%$ after $2 \mathrm{~min}$ at $106{ }^{\circ} \mathrm{C}$ (ASSIS et al., 2000). Seymour et al. (1991) isolated two PME isoforms from grapefruit and verified they differed regarding their association to carbohydrates and that; the removal of carbohydrates affected differently the enzyme thermostability. Furthermore, other factors may also influence PME activity as the purification degree of samples (FACHIN et al., 2002) and pH, which as reported by Anthon et al. (2002), a small change from $\mathrm{pH} 4.0$ to 4.4 affects significantly PME inactivation kinetics in tomato.

Soursop juice showed a decrease in residual polygalacturonase activity from $42.8 \mathrm{UA}_{\mathrm{Ug}}{ }^{-1} \mathrm{P}$ during the first minute of exposure to all temperatures tested (Fig. 5A). After this initial drop, the PG activity was mainly stable at temperatures equal or greater than $75^{\circ} \mathrm{C}$ until the end of the $30 \mathrm{~min}$ thermal, when they declined to approximately $20 \%$. The treatment with 55 and $65^{\circ} \mathrm{C}$ resulted in higher inconstancy of PG activity, although at the end of the exposure period, there was also a decline. The presence of isoforms with different thermostabilities could explain the results from treatments with temperatures above $65^{\circ} \mathrm{C}$, when the decline in activity of less stable isoforms would be responsible for the reduction in the residual activity observed in the first minute of treatment while more resistant isoforms would be responsible for the remaining activity until the end of 30 min treatment.

In cashew juice, 55 and $65^{\circ} \mathrm{C}$ treatments increased PG activity (initially 50.4 UA. $^{-1} \mathrm{P}$ ) after 3 and $1 \mathrm{~min}$, respectively, after which, activity declined continuously. At temperatures higher than $75^{\circ} \mathrm{C}$, activity declined slow and continuously reaching $40 \%$ after $30 \mathrm{~min}$ at 85 and $95^{\circ} \mathrm{C}$. The results observed for PG are similar to those found for PME in cashew juice (Fig. 4B) as the lower temperatures tested mainly enhanced enzyme activity.

Fachin et al. (2003) analyzed PG activity of tomato juice subjected for $5 \mathrm{~min}$ to temperatures from 40 to $90^{\circ} \mathrm{C}$ and observed two stages of inactivation, the first close to $55^{\circ} \mathrm{C}$ and the second at $65^{\circ} \mathrm{C}$, also suggesting the presence of isoenzymes with different thermostabilities. According to these authors, between 55 and $65^{\circ} \mathrm{C}$, the residual PG activity was due to the presence of PG1, which is a thermostable isoform. Anthon et al. (2002) also studied PG kinetics in CXD199 tomato juice and observed that thermostable PG1 remained active after exposure to $85^{\circ} \mathrm{C}$, while $\mathrm{PG} 2$ was completely inactivated at $75^{\circ} \mathrm{C}$. However, opposite results indicate the existence of less resistant isoforms in tomato juice subjected to thermal processing with a decline in $\mathrm{PG}$ activity to $12 \%$ after $2 \mathrm{~min}$ at $60^{\circ} \mathrm{C}$ (HSU, 2008). Crelier et al. (2001) also observed the complete inactivation of PG after 3 min at $93^{\circ} \mathrm{C}$.

The values of $k$ and $D$ found for soursop PG show that the thermal treatment was unable to completely inactivate the enzyme (Table 1). At $95^{\circ} \mathrm{C}, k$ and $D$ values were $0.065 \mathrm{~min}^{-1}$ and $35.4 \mathrm{~min}$, 
respectively. For the cashew juice, results show that PG was thermostable as the inactivation rate constant values were low, thus at $55^{\circ} \mathrm{C}, k$ value was $0.010 \mathrm{~min}$ ${ }^{-1}$ and it would take $230.3 \mathrm{~min}$ to reduce its activity in $90 \%$. There is a wide variation for the kinetic data of thermal inactivation of PG, as Terefe et al. (2009) evaluated 'Heinz' tomato juice and found $k$ values for PG that varied from $0.085 \mathrm{~min}^{-1}$ at $60^{\circ} \mathrm{C}$ to $0.57 \mathrm{~min}^{-1}$, at $75^{\circ} \mathrm{C}$. Fachin et al. (2002) also studied tomato- based products and reported $D$ value of a partially purified extract was $3.99 \mathrm{~min}$, meanwhile for the juice was $0.78 \mathrm{~min}$, both at $70^{\circ} \mathrm{C}$. Pressey (1986) evaluated PG activity in tomato puree, which presents a high amount of suspended solids and found inactivation constant of $0.0031 \mathrm{~min}^{-1}$, indicating that PG is more stable when associated with other substances derived from plant tissue than isolated.

TABLE 1- Kinetics of soursop and cashew apple juice enzymes.

\begin{tabular}{|c|c|c|c|c|c|c|}
\hline \multirow{2}{*}{ Enzyme } & \multirow{2}{*}{$\begin{array}{c}\text { Temperature } \\
\left({ }^{\circ} \mathrm{C}\right)\end{array}$} & \multicolumn{3}{|c|}{ Soursop } & \multicolumn{2}{|c|}{ Cashew apple } \\
\hline & & $\begin{array}{c}k \\
\left(\min ^{-1}\right)\end{array}$ & $\begin{array}{r}1 \\
(\mathrm{~m}\end{array}$ & & $\begin{array}{c}\boldsymbol{k} \\
\left(\mathrm{min}^{-1}\right)\end{array}$ & $\underset{(\min )}{D}$ \\
\hline \multicolumn{7}{|l|}{ SOD } \\
\hline & 55 & 0.003 & \multicolumn{2}{|c|}{767.66} & 0.003 & 767.66 \\
\hline & 65 & 0.118 & \multicolumn{2}{|c|}{19.51} & 0.044 & 52.34 \\
\hline & 75 & 0.359 & \multicolumn{2}{|c|}{6.41} & 0.023 & 100.13 \\
\hline & 85 & 0.287 & \multicolumn{2}{|c|}{8.02} & 0.009 & 255.88 \\
\hline & 95 & 0.262 & \multicolumn{2}{|c|}{8.79} & 0.006 & 383.83 \\
\hline \multicolumn{7}{|l|}{ CAT } \\
\hline & 55 & - & & & 0.007 & 329.00 \\
\hline & 65 & - & & & 0.008 & 287.87 \\
\hline & 75 & - & & & 0.028 & 82.25 \\
\hline & 85 & - & & & 0.019 & 121.21 \\
\hline & 95 & - & & & 0.024 & 95.95 \\
\hline \multicolumn{7}{|c|}{ Peroxidase $^{a}$} \\
\hline & 55 & 0.028 & 82.50 & & . & - \\
\hline & 65 & 0.190 & 12.12 & & 14 & 164.50 \\
\hline & 75 & 0.168 & 13.70 & & 21 & 109.66 \\
\hline & 85 & 0.224 & 10.28 & & 73 & 31.54 \\
\hline & 95 & 0.236 & 9.75 & & 37 & 62.24 \\
\hline \multicolumn{7}{|l|}{ PME } \\
\hline & 55 & 0.012 & \multicolumn{2}{|c|}{191.91} & - & - \\
\hline & 65 & 0.013 & \multicolumn{2}{|c|}{177.15} & - & - \\
\hline & 75 & 0.018 & \multicolumn{2}{|c|}{127.94} & 0.018 & 127.94 \\
\hline & 85 & 0.016 & \multicolumn{2}{|c|}{143.93} & 0.011 & 209.94 \\
\hline & 95 & 0.021 & \multicolumn{2}{|c|}{109.66} & 0.021 & 109.66 \\
\hline \multicolumn{7}{|l|}{ PG } \\
\hline & 55 & 0.057 & 40.40 & & 10 & 230.30 \\
\hline & 65 & 0.044 & 52.34 & & 41 & 56.17 \\
\hline & 75 & 0.059 & 39.03 & & 36 & 60.60 \\
\hline & 85 & 0.047 & 49.00 & & 35 & 65.80 \\
\hline & 95 & 0.065 & 35.43 & & 50 & 46.09 \\
\hline
\end{tabular}

${ }^{\mathrm{a}} \mathrm{G}-\mathrm{POD}$ for soursop and APX for cashew apple juice. 


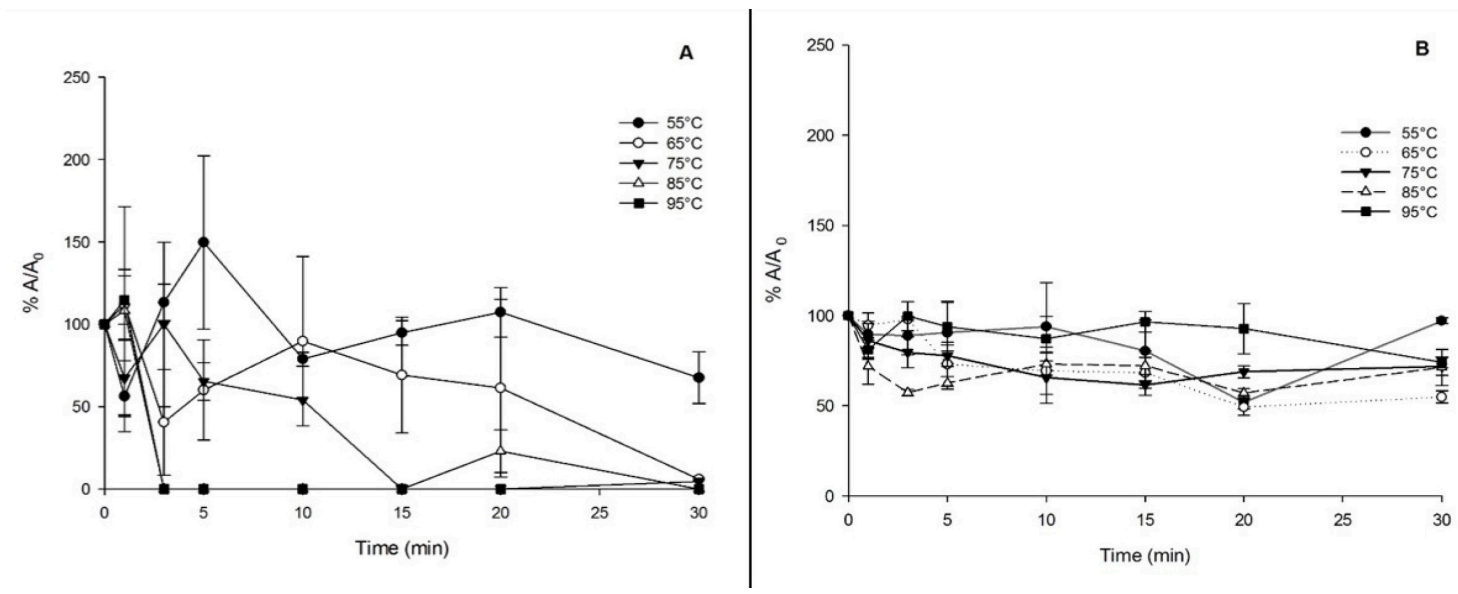

FIGURE 1- Thermal inactivation of SOD. Residual activity in soursop (A) and cashew apple (B) juice heated to $55(\bullet), 65,(\mathrm{O}), 75(\square), 85(\square)$ or $95^{\circ} \mathrm{C}(\diamond)$ for the indicated times.

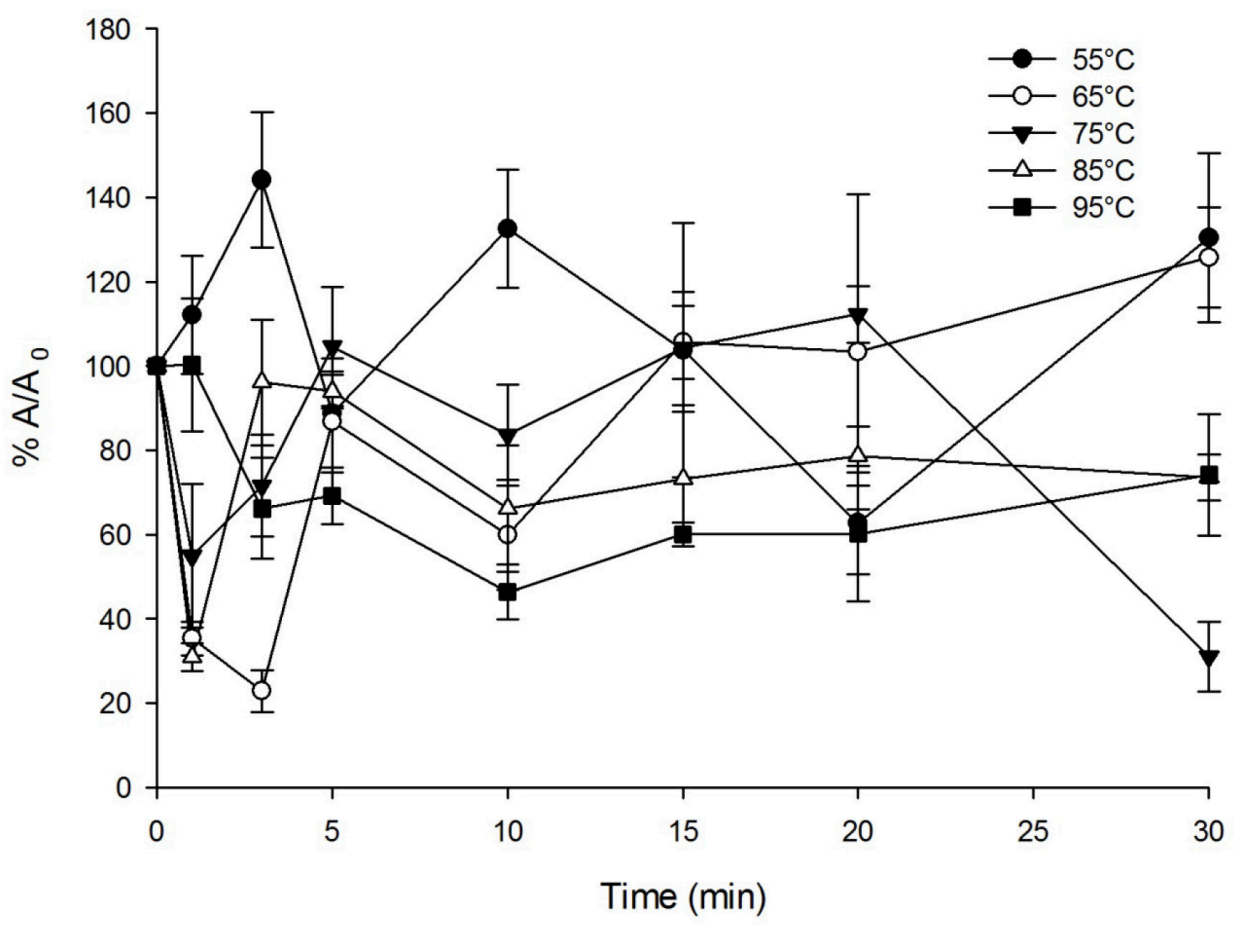

FIGURE 2-Thermal inactivation of CAT. Residual activity in cashew apple juice heated to $55(\bullet), 65,(\mathrm{O})$, $75(\square), 85(\square)$ or $95^{\circ} \mathrm{C}(\diamond)$ for the indicated times. 


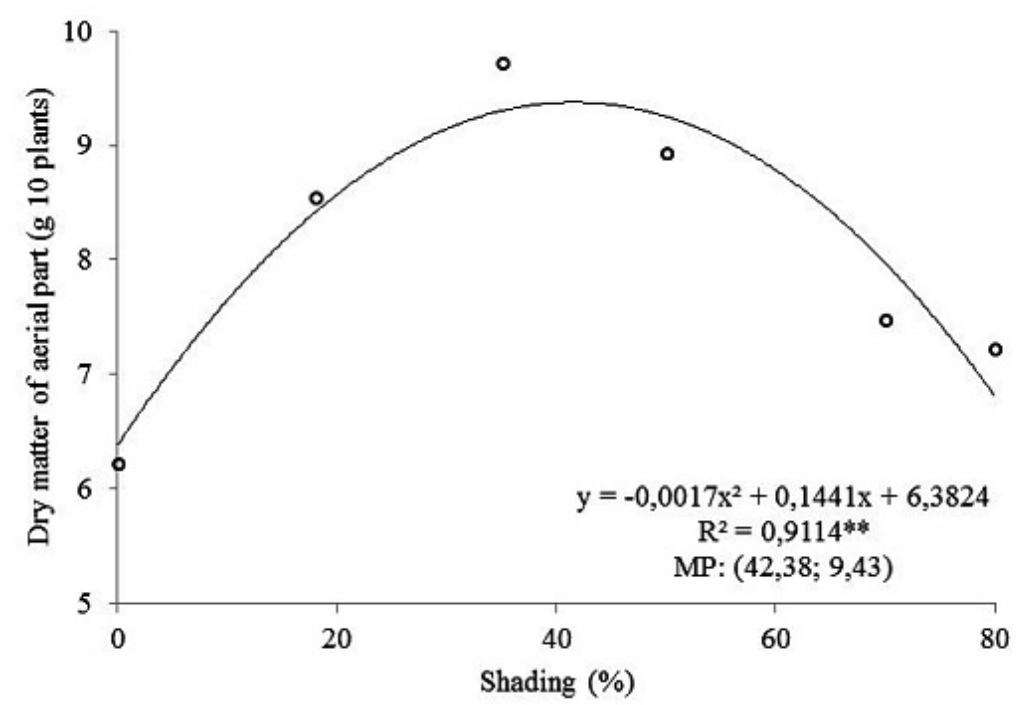

FIGURE 3- Thermal inactivation of G-POD and APX. Residual activity of G-POD in soursop (A) and of APX in cashew apple (B) juice heated to $55(\bullet), 65,(\mathrm{O}), 75(\square), 85(\square)$ or $95^{\circ} \mathrm{C}(\bullet)$ for the indicated times.
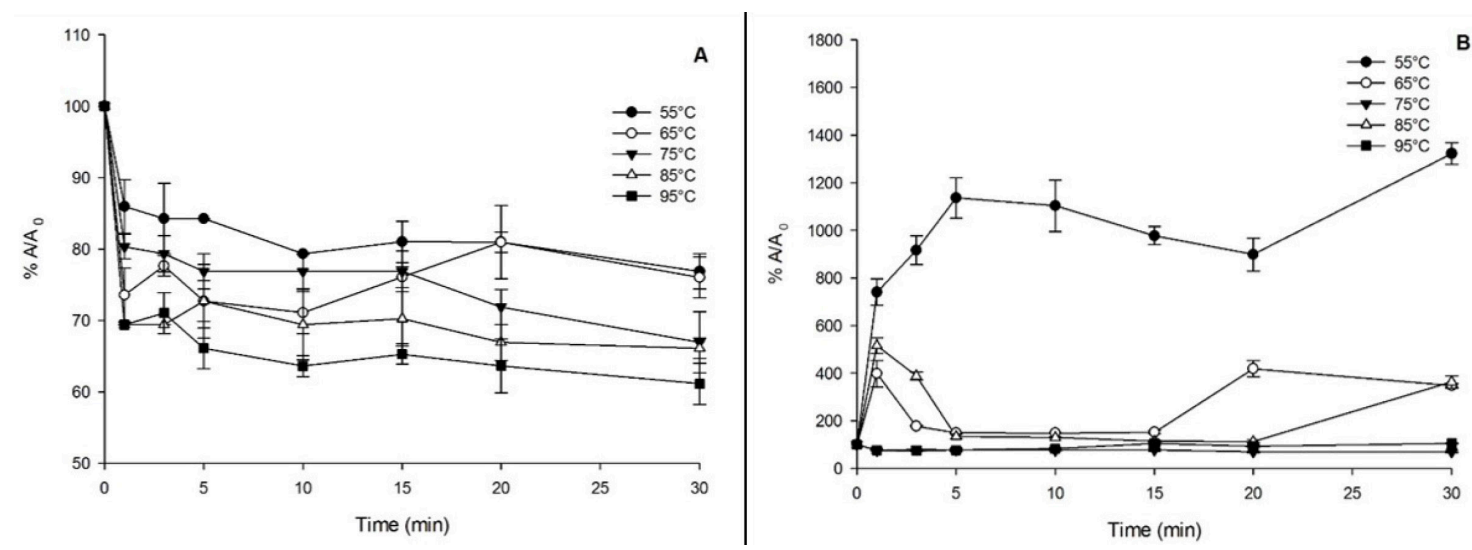

FIGURE 4- Thermal inactivation of PME. Residual activity in soursop (A) and cashew apple (B) juice heated to $55(\bullet), 65,(\mathrm{O}), 75(\square), 85(\square)$ or $95^{\circ} \mathrm{C}(\bullet)$ for the indicated times.
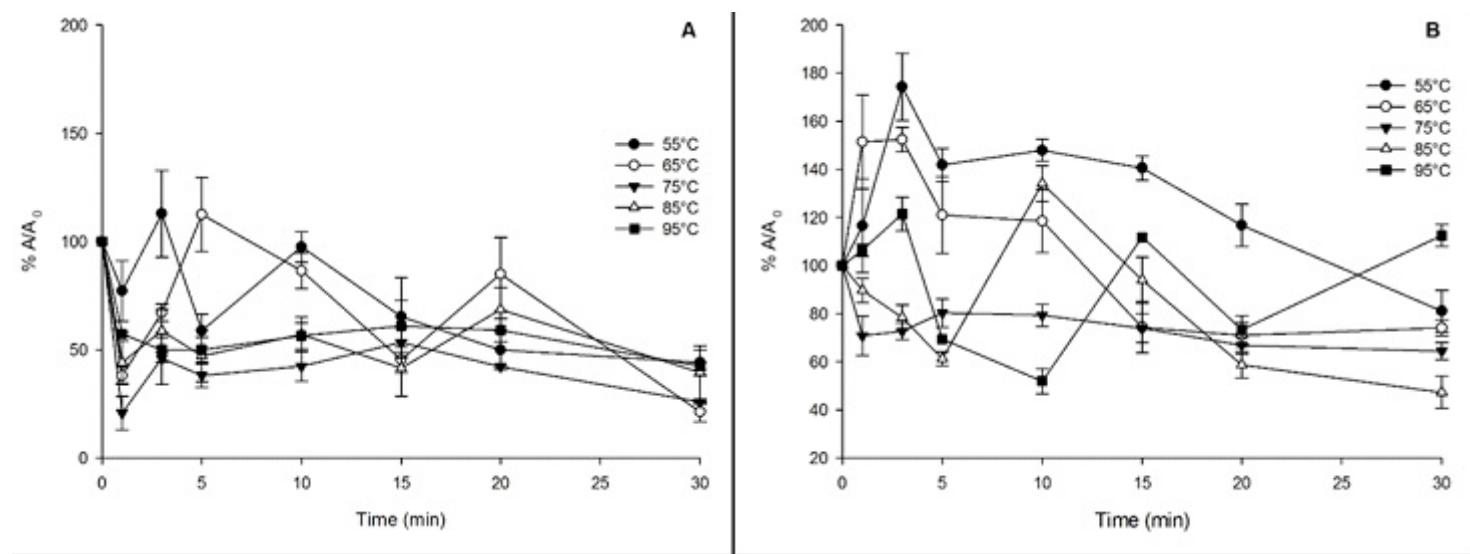

FIGURE 5- Thermal inactivation of PG. Residual activity in soursop (A) and cashew apple (B) juice heated to $55(\bullet), 65,(\bigcirc), 75(\square), 85(\square)$ or $95^{\circ} \mathrm{C}(\diamond)$ for the indicated times. 


\section{CONCLUSIONS}

In general, the enzymes from cashew apple juice were more thermoresistant than those from soursop juice, indicating that juice composition influences the enzymes stability. In cashew apple, the treatment at $75^{\circ} \mathrm{C}$ for 30 min presented the best results when only the residual activity is considered. Under these conditions, PME and PG were inactivated in 30 and $36 \%$, respectively; meanwhile, the antioxidants enzymes SOD, APX and CAT residual activity was retained. PME was the most resistant to high temperatures keeping $100 \%$ of its residual activity after $30 \mathrm{~min}$ at $95^{\circ} \mathrm{C}$, followed by CAT (74\%), SOD (74\%), APX (56\%) and PG, 44\%.

The exposure of soursop juice to $55^{\circ} \mathrm{C}$ for $30 \mathrm{~min}$ was the most effective treatment in reducing POD, PME and PG activities; however it did not reduce SOD activity. PME was the most thermoresistant enzyme retaining $61 \%$ of activity after $30 \mathrm{~min}$ at $95^{\circ} \mathrm{C}$, meanwhile POD was the most sensitive being completely inactivated after $1 \mathrm{~min}$ at $65^{\circ} \mathrm{C}$.

\section{ACKNOWLEDGEMENTS}

This study was supported by the Instituto Nacional de Frutos Tropicais INCT-FT/CNPq.

\section{REFERENCES}

ABBO, E.S.; OLURIN, T.O.; ODEYEMI, G. Studies on the storage stability of soursop (Annona muricata L.) juice. African Journal of Biotechnology, Nairobi, v.5 p.1808-1812, 2006.

AMANKO, K.; CHEN, G.X.; ASADA, K. Separate assays specific for ascorbate peroxidase and guaiacol peroxidase and for chloroplastic and cytosolic isozymes of ascorbate peroxidase in plants. Plant Cell Physiology, Oxford, v.35, p.497-504, 1994.

ANTHON, G.E.; SEKINE, Y.; WATANABE, N.; BARRETT, D.M. Thermal Inactivation of Pectin Methylesterase, Polygalacturonase, and Peroxidase in Tomato Juice. Journal of Agricultural and Food Chemistry, Washington, v.50, p.6153-6159, 2002.

ASSIS, S.A.; LIMA, D.C.; OLIVEIRA, O.M.M.F. Acerola's pectin methylesterase: studies of heat inactivation. Food Chemistry, London, v.71, p.465-467, 2000.
BEAUCHAMP, C.; FRIDOVICH, I. Superoxide dismutase: improved assays and an assay applicable to acrylamide gels. Analytical Biochemistry, San Diego, v.44, p.276-287, 1987.

BEERS JR, R.F.; SIZER, I.W. A spectrophotometric method for measuring the breakdown of hydrogen peroxide by catalase. Journal of Biology and Chemistry, Baltimore, v.195, p.133-140, 1952.

BRADFORD, M.M. A rapid and sensitive method for the quanification of microgram quantities of protein utilising the principle of protein-dye binding. Analytical Biochemistry, San Diego, v.722, p.248-254, 1976.

BREUSEGEM, F.V.; VRANOVÁ, E.; DAT, J.F.; INZÉ, D. The role of active oxygen species in plant signal transduction. Plant Science, Limerick, v.161, p.405-414, 2001.

BUESCHER, R.W.; FURMANSKI, R.J. Role of pectinesterase and polygalacturonase in the formation of woolliness in peaches. Journal of Food Science, Champaign, Champaign, v.43, p.264-266, 1978.

CARILlON, J.; NOTIN, C.; SCHMITT, K.; SIMONEAU, G.; LACAN, D. Dietary supplementation with a superoxide dismutase-melon concentrate reduces stress, physical and mental fatigue in healthy people: a randomised, doubleblind, placebo-controlled trial. Nutrients, Basel, v.6, p.2348-2359, 2014.

CLEMENTE, E. Peroxidase from oranges (Citrus sinensis (L.) Osbeck). European Food Research and Technology, Berlin, v.215, p.164-168, 2002.

CORREIA, L.F.M.; FARAONI, A.S.; PINHEIROSANT'ANA, H.M. Effects of industrial foods processing on vitamins stability. Brazilian Journal of Food and Nutrition, Campinas, v.19, p.83-95, 2008.

CRELIER, S.; ROBERT, M.C.; CLAUDE, J.; JUILLERAT, M.A. Tomato (Lycopersiconesculentum) pectin methylesterase and polygalacturonase behaviors regarding heat- and pressure-induced inactivation. Journal of Agricultural and Food Chemistry, Washington, v.49, p.5566-5575, 2001. 
DAMASCENO, L.F.; FERNANDES, F.A.N.; MAGALHÃES, M.M.A.; BRITO, E.S. Nonenzymatic browning in clarified cashew apple juice during thermal treatment: Kinetics and process control. Food Chemistry, London, v.106, p.172179, 2008.

DE MARCO, A.; PINTON, R.; FISCHERSCHLIEBS, E.; VARANINI, Z. Possible interaction between peroxidase and $\mathrm{NAD}(\mathrm{P}) \mathrm{H}$-dependent nitrate reductase activities of plasma membranes of corn roots. Journal of Experimental Botany, Lancaster, v.46, p.1677-1683, 1995.

FACHIN, D.; LOEY, A.; BINH, L.N.; VERLENT, I.; INDRAWATI; HENDRICKX, M. Inactivation kinetics of polygalacturonase in tomato juice. Innovative Food Science and Emerging Technologies, Amsterdam, v.4, p.135-142, 2003.

FACHIN, D.; VAN LOEY, A.M.; NGUYEN, B.L.; VERLENT, I.; INDRAWATI; HENDRICKX, M.E. Comparative study of the inactivation kinetics of pectinmethylesterase in tomato juice and purified form. Biotechnology Progress, Washington, v.18, p.739-744, 2002.

FAO. Food and Agriculture Organization of the United Nations Statistics Division. 2014. Disponível em: <http:/faostat3.fao.org/faostatgateway/go/to/ download/Q/QC/E $>$.

FREITAS, A.A.; FRANCELIN, M.F.; HIRATA, G.F.;CLEMENTE, E.; SCHMIDT, F.L. Activities of peroxidase (POD) and polyphenoloxidase (PPO) enzymes in grape fruit cultivars benitaka and rubi and in their juices and jams. Food Science and Technology, Campinas, v.28, p.172-177, 2008.

GIANNOPOLITIS, C.N.; RIES, S.K. Superoxide dismutase. I. Occurrence in higher plants. Plant Physiology, Chicago, v.59, p.309-314, 1977.

GUMMADI, S.N.; PANDA, T. Purification and biochemical properties of microbial pectinases: a review. Process Biochemistry, New York, v.38, p.987-996, 2003.

HIRSCH, A.H.; FÖRCH, K.; NEIDHART, S.; WOLF, G.; CARLE, R. Effects of thermal treatments and storage on pectin methylesterase and peroxidase activity in freshly squeezed orange juice. Journal of Agricultural and Food Chemistry, Washington, v.56, p.5691-5699, 2008.
HIRSCH, A.H.; KNAUSS, A.; CARLE, R.; NEIDHART, S. Impact of minimal heat-processing on pectin methylesterase and peroxidase activity in freshly squeezed Citrus juices. European Food Research and Technology, Berlin, v.232, p.71-81, 2011.

Hsu, K.C. Evaluation of processing qualities of tomato juice induced by thermal and pressure processing. LWT-Food Science and Technology, Amsterdam, v.41, p.450-459, 2008.

JAKOB, A.; BRYJAK, J.; WOJTOWICZ, H.; ILlEOVA, V.; ANNUS, J.; POLAKOVIC, M. Inactivation kinetics of food enzymes during ohmic heating. Food Chemistry, London, v.123, p.369-376, 2010.

JORDAN, S.L.; PASCUAL, C.; BRACEY, E.; MACKEY, B.M. Inactivation and injury of pressureresistant strains of Escherichia coli O157 and Listeria monocytogenes in fruit juice. Journal of Applied Microbiology, Oxford, v.91, p.463-9, 2001.

KERTESZ, Z.I. Pectic enzymes. In: COLOWICK, S.P.; KAPLAN, N.O. Methods in enzymology. New York: Academic Press, 1955. 1581p.

KORNER, B.; ZIMMERMANN, G.; BERK, Z. Orange pectinesterase: purification, properties and effect on cloud stability. Journal of Food Science, Champaign, v.45, p.1203-1206, 1980.

LALLÈS, J.P.; LACAN, D.; DAVID, J.P. A melon pulp concentrate rich in superoxide dismutase reduces stress proteins along the gastrointestinal tract of pigs. Nutrients, Basel, v.27, p.358-363, 2011.

LEITE, K.M.S.C.; TADIOTTI, A.C.; BALDOCHI, D.; OLIVEIRA, O.M.M.F. Partial purification, heat stability and kinetic characterization of the pectinmethylesterase from Brazilian guava, Paluma cultivars. Food Chemistry, London, v.94, p.565$572,2006$.

LIMA, M.A.C.; ALVES, R.E.; FILGUEIRAS, H.A.C. Changes related to softening of soursop during postharvest maturation. Brazilian Agricultural Research, Brasília, v.41, p.1707-1713, 2006.

MAC DONALD, H.M.; EVANS, R.; SPENCER, W.J. The use of continuous-flow electroforesis to remove pectin in the purification of the minor pectinesterases in lemon fruits (Citrus lemon). Journal of the Science and Food Agriculture, Chichester, v.64, p.129-134, 1997. 
MATSUI, K.N.; GUT, J.A.W.; OLIVEIRA, P.V.; TADINI, C.C. Inactivation kinetics of polyphenol oxidase and peroxidase in green coconut water by microwave processing. Journal of Food Engineering, New York, v.88, p.169-176, 2008.

MEYER, A.S.; ISAKSEN, A. Application of enzymes as food antioxidants. Trends in Food Science \& Technology, Kidlington, v.6, p.300-304, 1995.

MIKA, A.; LUTHJE, S. Properties of guaiacol peroxidase activities isolated from corn root plasma membranes. Plant Physiology, Chicago, v.132, p.1489-1498, 2003.

MORAN, J.F.; JAMES, E.K.; RUBIO, M.C.; SARATH, G.; KLUCA, S.R.V.; BECANA, M.L. Functional characterization and expression of a cytosolic iron-superoxide dismutase from Cowpea root nodules. Plant Physiology, Chicago, v.133, p.773-782, 2003.

NAKANO, Y.; ASADA, K. Hydrogen peroxide is scavenged by ascorbate-specific peroxidases in spinach chloroplast. Plant \& Cell Physiology, Oxford, v. 22, p.867-880, 1981.

NELSON, N.A. A photometric adaptation of Somogyi method for the determination of glucose. The Journal of Biological Chemistry, Baltimore, v.153, p.375-380, 1944.

NOCTOR, G.; FOYER, C.H. Ascorbate and glutathione keeping active oxygen under control. Annual Review Plant Physiology and Plant Molecular Biology, Palo Alto, v.49, p.249-279, 1998.

PAEPE, D.DE; VALKENBORG, D.; COUDIJZER, K.; NOTEN, B.; DE LOOSE, M.; VOORSPOELS, S.; DIELS, L.; VAN DROOGENBROECK, B. Thermal degradation of cloudy apple juice phenolics constituents. Food Chemistry, London, v.162, p.176-185, 2014.

PASSARDI, F.; COSIO, C.; PENEL, C.; DUNAN, D.C. Peroxidases have more functions than a Swiss army knife. Plant Cell Reports, Berlin, v.24, p.255-265, 2005.

POŁATA, H.; WILIN' SKA, A.; BRYJAK, J.; POLAKOVIC, M. Thermal inactivation kinetics of vegetable peroxidases. Journal of Food Engineering, New York, v.91, p.387-391, 2009.
PRESSEY, R. Extraction and assay of tomato polygalacturonases. HortScience, St Joseph, v.21, p.490-492, 1986.

RAYAN, A.M.M.; GAB-ALLA, A.A.; SHATTA, A.A.; EL-SHAMEI, Z.A.S. Thermal inactivation kinetics of quality-related enzyms in cauliflower (Brassica oleracea var. botrytis). European Food Research and Technology, Berlin, v.232, p.319326, 2011.

RIVAS, A.; RODRIGO, D.; MARTINEZ, A.; BARBOSA-CÁNOVAS, G.V.; RODRIGO, M. Effect of PEF and heat pasteurization on the physical-chemical characteristics of blended orange and carrot juice. LWT- Food Science and Technology, Amsterdam, v.39, p.1163 - 1170, 2006.

SANTOS, R.; HE'ROUART, D.; PUPPO, A.; TOUATI D. Critical protective role of bacterial superoxide dismutase in Rhizobium-legume symbiosis. Molecular Microbiology, Oxford, v.38, p. $750-759,2000$.

SEYMOUR, T.A.; PRESTON, J.F.; WICKER, L.; LINDSAY, J.A.; MARCHALL, M.R. Purification and propertiee of pectinesterases of Marsh white grapefruit pulp. Journal of Agricultural and Food Chemistry, Washington, v.39, p.1080-1085, 1991.

TAYEFI-NASRABADI, H.; DEHGHAN, G.; DAEIHASSANI, B.; MOVAFEGI, A.; SAMADI, A. Some biochemical properties of guaiacol peroxidases as modified by salt stress in leaves of salt-tolerant and salt-sensitive safflower (Carthamus tinctorius L.cv.) cultivars. African Journal of Biotechnology, Nairobe, v.10, p.751-763, 2011.

TEIXERA, C.K.B.; NEVES, E.C.A.; PENA, R.S Study of soursoap pulp pasteurization. Brazilian Journal of Food Nutrition, Araraquara, v.17, p.251-257, 2006.

TEREFE, N.S.; GAMAGE, M.; VILKHU, K.; SIMONS, L.; MAWSON, R.; VERSTEEG, C. The kinetics of inactivation of pectin methylesterase and polygalacturonase in tomato juice by thermosonication. Food Chemistry, London, v.117, p.20-27, 2009.

WISSEMAN, K.W.; LEE, C.Y. Purification of grape polyphenoloxidas with hydrophobic chromatography. Journal of Chromatography, Amsterdam, v.192, p.232-235, 1980. 